\title{
Export of ${ }^{134} \mathrm{Cs}$ and ${ }^{137} \mathrm{Cs}$ in the Fukushima river systems at heavy rains by Typhoon Roke in September 2011
}

\author{
S. Nagao ${ }^{1}$, M. Kanamori ${ }^{2}$, S. Ochiai ${ }^{1}$, S. Tomihara ${ }^{3}$, K. Fukushi ${ }^{4}$, and M. Yamamoto ${ }^{1}$ \\ ${ }^{1}$ Low Level Radioactivity Laboratory, Institute of Nature and Environmental Technology, Kanazawa University, Nomi, \\ Ishikawa 923-1224, Japan \\ ${ }^{2}$ Graduate School of Natural Science and Technology, Kanazawa University, Kakuma, Kanazawa, Ishikawa 920-1192, Japan \\ ${ }^{3}$ Aquamarine Fukushima, Obama, Iwaki, Fukushima 971-8101, Japan \\ ${ }^{4}$ Division of Earth Dynamics, Institute of Nature and Environmental Technology, Kanazawa University, Kakuma, Kanazawa, \\ Ishikawa 920-1192, Japan \\ Correspondence to: S. Nagao (nagao37@staff.kanazawa-u.ac.jp)
}

Received: 31 December 2012 - Published in Biogeosciences Discuss.: 15 February 2013

Revised: 19 July 2013 - Accepted: 27 July 2013 - Published: 2 October 2013

\begin{abstract}
At stations on the Natsui River and the Same River in Fukushima Prefecture, Japan, effects of a heavy rain event on radiocesium export were studied after Typhoon Roke during 21-22 September 2011, six months after the Fukushima Dai-ichi Nuclear Power Plant accident. Radioactivity of ${ }^{134} \mathrm{Cs}$ and ${ }^{137} \mathrm{Cs}$ in river waters was $0.009-0.098 \mathrm{~Bq} \mathrm{~L}^{-1}$ in normal flow conditions during July-September 2011, but it increased to $0.85 \mathrm{~Bq} \mathrm{~L}^{-1}$ in high flow conditions because of heavy rains occurring with the typhoon. The particulate fractions of ${ }^{134} \mathrm{Cs}$ and ${ }^{137} \mathrm{Cs}$ were $21-56 \%$ of total radiocesium in the normal flow condition, but were close to $100 \%$ after the typhoon. These results indicate that the pulse input of radiocesium associated with suspended particles from land to coastal ocean occurred because of the heavy rain event. Export flux of ${ }^{134} \mathrm{Cs}$ and ${ }^{137} \mathrm{Cs}$ attributable to the heavy rain accounts for $30-50 \%$ of the annual radiocesium flux from inland to coastal ocean region in 2011. Results show that rain events are one factor contributing to the transport and dispersion of radiocesium in river watersheds and coastal marine environments.
\end{abstract}

\section{Introduction}

A nuclear accident at the Fukushima Dai-ichi Nuclear Power Plant (NPP) occurred after the 2011 Tōhoku earthquake and tsunami. About $15 \mathrm{PBq}$ of both ${ }^{134} \mathrm{Cs}$ and ${ }^{137} \mathrm{Cs}$ was released from the NPP as a result of venting operations and hydro- gen explosions (Japanese Government, 2011; Chino et al., 2011). Surface deposition of ${ }^{134} \mathrm{Cs}$ and ${ }^{137} \mathrm{Cs}$ shows considerable external radioactivity in a zone extending northwest from the NPP, about $20 \mathrm{~km}$ wide and $50-70 \mathrm{~km}$ long inside the $80 \mathrm{~km}$ zone of the NPP (MEXT, 2011; Yoshida and Takahashi, 2012). Moderate radioactivity $\left(100-600 \mathrm{kBq} \mathrm{m}^{2}\right)$ was also detected in the Naka-dori region. The deposition pattern is explained by emission rates of ${ }^{134} \mathrm{Cs}$ and ${ }^{137} \mathrm{Cs}$ coupled with wind direction and precipitation (Morino et al., 2011).

A major part of radiocesium deposited on the ground surface is present at the surface to $5 \mathrm{~cm}$ depth (MEXT, 2012a; Koarashi et al., 2012). Chemical extraction of ${ }^{134} \mathrm{Cs}$ and ${ }^{137} \mathrm{Cs}$ from selected soil samples has revealed that both radionuclides in the soil are only slightly water-soluble. Even the fraction extracted with $1 \mathrm{M}$ ammonium acetate was only approximately $10 \%$ (Matsunaga et al., 2013). However, ${ }^{134} \mathrm{Cs}$ and ${ }^{137} \mathrm{Cs}$ have been transported from contaminated watersheds to rivers in Fukushima Prefecture since the Fukushima Dai-ichi NPP accident (MEXT, 2012a; Sakaguchi et al., 2012). Similar outcomes were observed for the Pripyat River and Dnieper River in Ukraine after the Chernobyl accident in 1986 (IAEA, 2006a). The migration of ${ }^{137} \mathrm{Cs}$ has decreased markedly over time in river waters from Ukraine (UHMI, 2004; IAEA, 2006b) and Finland (Saxén and Ilus, 2001). The radioactivity of ${ }^{137}$ Cs shows little change from upstream to downstream of the exclusion zone in the Pripyat River of the Chernobyl area (IAEA, 2006a). An increase in radioactivity of ${ }^{134} \mathrm{Cs}$ and ${ }^{137} \mathrm{Cs}$ in 
river waters was also found in the Chernobyl area during a spring flood event (IAEA, 2006a, b) and in northwestern Italy from a delayed release in summer during ice and snow melting in mountain areas (Spezzano et al., 1994). The transport of materials generally depends on watershed conditions such as vegetation, slope, soil types, and spring snow-melting. Clarifying the migration behavior of radiocesium and its controlling factors is important for future prediction of its dispersion in Fukushima Prefecture, Japan.

To elucidate the short-term to long-term impacts of the Fukushima Dai-ichi NPP accident on riverine and coastal marine ecosystems, the Japanese Government has been monitoring the radioactivity of ${ }^{134} \mathrm{Cs}$ and ${ }^{137} \mathrm{Cs}$ in river systems in Fukushima Prefecture (MEXT, 2012b). Japanese rivers have short lengths, high riverbed slopes, and high river regime coefficients (ratio of maximum / minimum discharge; Suetsugu, 2005). Annual mean precipitation is generally high (e.g., $1718 \mathrm{~mm}$ during 1971-2000) because of tsuyu (the rainy season in Japan), typhoons, and snow-melting events in spring (MLTI, 2012). Matsunaga et al. (1991) reported that the radioactivity of ${ }^{137} \mathrm{Cs}$ derived from fallout increased in the Kuji River during high flow conditions caused by rain events. Nagano et al. (2003) pointed out that variations of suspended form and dissolved form concentrations of elements in the Kuji River waters occurred as a function of the water discharge rates. It is important that we evaluate rain event effects on radiocesium export from land to ocean in the Fukushima area.

This study was conducted to investigate the transport of ${ }^{134} \mathrm{Cs}$ and ${ }^{137} \mathrm{Cs}$ in river systems in Fukushima Prefecture after rain events. This report describes monitoring results of radioactivity of ${ }^{134} \mathrm{Cs}$ and ${ }^{137} \mathrm{Cs}$ in river waters at two rivers after a heavy rain event, a typhoon, in September 2011. Field experiments were conducted at the Natsui River and the Same River in the southern part of Fukushima Prefecture, Japan. We examined the transport behavior of radiocesium and estimated its export flux from inland to coastal areas.

\section{Materials and methods}

Typhoon Roke (T1115) struck Japan on 21 September and subsequently weakened to an extra-strong tropical cyclone on 22 September 2011 (JMA, 2011). The typhoon precipitated more than $400 \mathrm{~mm}$ of rain daily in parts of eastern and western Japan (JMA, 2011). Fukushima Prefecture recorded rainfall of 100-200 mm during 15-22 September. The daily rainfall on 21 September was $137 \mathrm{~mm}$ because of the impact of Typhoon Roke at Onahama of Iwaki city, located in the southern coastal region of Fukushima and in a watershed of the Natsui River. This value is about one-tenth of the annual mean rainfall (1409 mm for 1981-2010; JMA, 2012).

The sampling locations are presented in Fig. 1. This study investigated Natsui River and Same River, each flowing to the Pacific coast through less-contaminated areas



Fig. 1. Natsui River and the Same River sampling locations. Closed circles represent sampling stations. Open circles show a station for monitoring precipitation at Onahama. Open inverted triangles represent water level observatory sites.

( $<100 \mathrm{kBq} \mathrm{m}^{2}$ : MEXT, 2011). The Natsui River watershed area is $749 \mathrm{~km}^{2}$. That of the Same River is $600 \mathrm{~km}^{2}$. The Natsui River length is $67 \mathrm{~km}$. That of the Same River is $58 \mathrm{~km}$. The annual mean water discharge data in 2011 were $17.6 \mathrm{~m}^{3} \mathrm{~s}^{-1}$ for the Natsui River and $21.4 \mathrm{~m}^{3} \mathrm{~s}^{-1}$ for the Same River (Fukushima Prefectural Government, 2012). The water discharge data are presented in Fig. 2. River water samples (10-20 L) were collected at normal flow conditions on 12 and 27 July, 13 September, 24 November, 6 December, and 22 September in high-flow conditions after Typhoon Roke in 2011. Sampling was conducted at the Iwaki-bashi bridge over the Natsui River and the Eguri-Ohashi bridge over the Same River.

In river waters after the heavy rain event with the typhoon, particles were separated using centrifugation and filtration with No. 5A (approx. pore size of $7 \mu \mathrm{m}$ ) filters and $0.45 \mu \mathrm{m}$ pore size membrane filters. In this study, suspended solids using centrifugation are designated as "fraction 1" (FR1). The suspended solids on the filters are designated as "fraction 2" (FR2) for those filtered with No. 5A filters and "fraction 3" (FR3) for those collected with $0.45 \mu \mathrm{m}$ filters.

The radioactivity of ${ }^{134} \mathrm{Cs}$ and ${ }^{137} \mathrm{Cs}$ in the filtered river waters was measured as dissolved forms of radiocesium with gamma-ray spectrometry using ammonium 


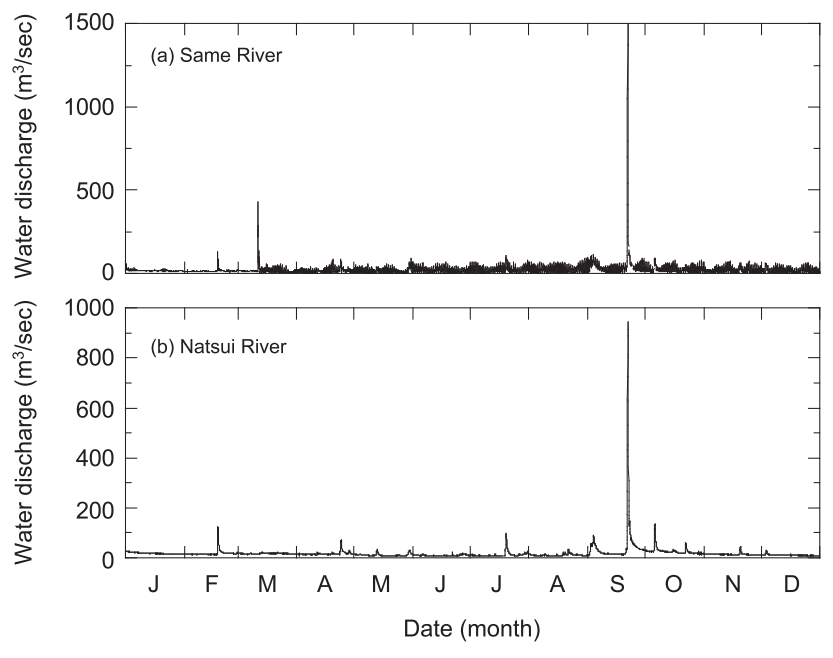

Fig. 2. Water discharge of the Natsui River and the Same River in 2011. Data were referred from the Fukushima Prefectural Government.

molybdophosphate (AMP)/Cs compound method (Tanaka et al., 2006). The ${ }^{134} \mathrm{Cs}$ and ${ }^{137} \mathrm{Cs}$ were measured using gamma-ray spectrometry with a low background Ge detector at the Low Level Radioactivity Laboratory and the Ogoya Underground Laboratory of Kanazawa University for 1-3 days (Hamajima and Komura, 2010). The gamma lines were used for the activity calculation at $605 \mathrm{keV}$ and $795 \mathrm{keV}$ for ${ }^{134} \mathrm{Cs}$ and $661 \mathrm{keV}$ for ${ }^{137} \mathrm{Cs}$. The cascade summing effect was corrected for ${ }^{134} \mathrm{Cs}$ using a Fukushima contaminated soil sample. The decay correction of radioactive concentration for ${ }^{134} \mathrm{Cs}$ and ${ }^{137} \mathrm{Cs}$ was done at each sampling date. The deposited solids and suspended solids on the filters were also measured using gamma-ray spectrometry after drying them at room temperature. The total radioactivity of ${ }^{134} \mathrm{Cs}$ and ${ }^{137} \mathrm{Cs}$ is the sum of radioactivity for the suspended solids and filtered river waters.

In normal flow conditions on 12 July and 13 September, dissolved and particulate forms of radiocesium were separated sequentially using cartridge filters with pore sizes of $10 \mu \mathrm{m}, 1 \mu \mathrm{m}$, and $0.45 \mu \mathrm{m}$. The radioactivity of ${ }^{134} \mathrm{Cs}$ and ${ }^{137} \mathrm{Cs}$ was recorded as total (dissolved and particulate forms) for the raw river waters and as dissolved for the filtered waters. The ${ }^{134} \mathrm{Cs}$ and ${ }^{137} \mathrm{Cs}$ particulate phases were estimated by subtracting the radioactivity for the dissolved phase from the total radioactivity.

The mineral composition of riverine suspended solids on the filters and of deposited solids after the heavy rain event was analyzed using X-ray diffraction (XRD). The XRD analysis of powdered samples mounted on glass slides was conducted using an Ultima IV (Rigaku Corp.) diffractometer using $\mathrm{Cu} K \alpha$ radiation operated at $40 \mathrm{kV}$ and $30 \mathrm{~mA}$ from $2^{\circ}$ to $65^{\circ}$. Suspended solids on $\mathrm{GF} / \mathrm{F}$ and membrane filters were also mounted on glass slides and were measured for clay mineral composition.

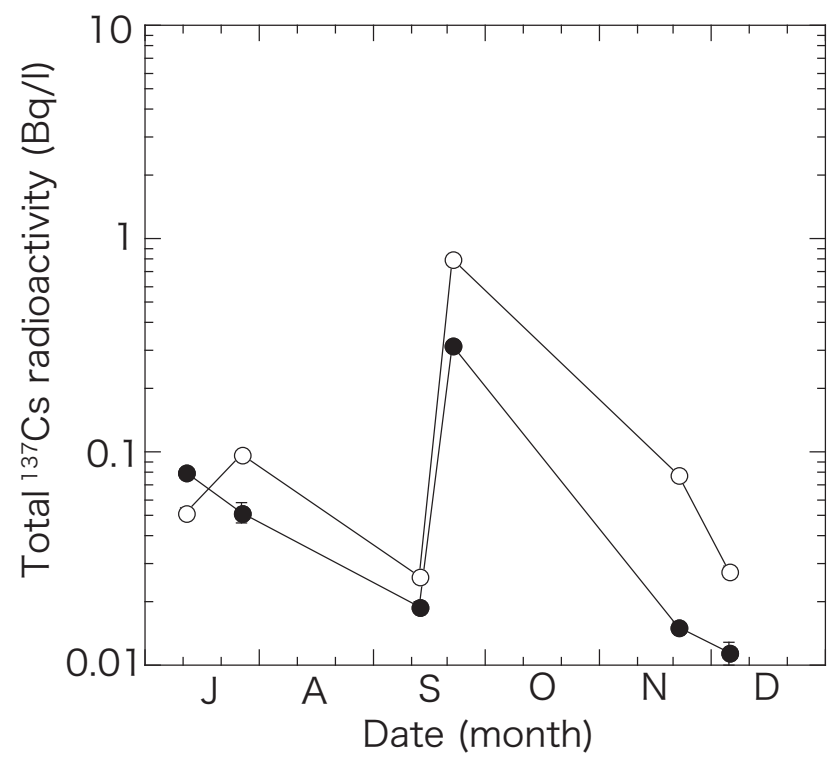

Fig. 3. Total radioactivity of ${ }^{137} \mathrm{Cs}$ in water samples from the Natsui River (o) and the Same River (•) during July-December 2011.

\section{Results and discussion}

\subsection{Radioactivity of ${ }^{134} \mathrm{Cs}$ and ${ }^{137} \mathrm{Cs}$}

Total radioactivity measurements of ${ }^{134} \mathrm{Cs}$ and ${ }^{137} \mathrm{Cs}$ in the river waters are shown in Table 1 and Fig. 3. The respective radioactivity measurements of ${ }^{134} \mathrm{Cs}$ and ${ }^{137} \mathrm{Cs}$ were $0.009 \mathrm{~Bq} \mathrm{~L}^{-1}-0.089 \mathrm{~Bq} \mathrm{~L}^{-1}$ and $0.011 \mathrm{~Bq} \mathrm{~L}^{-1}$ $0.098 \mathrm{BqL}^{-1}$ in the normal flow condition. The radioactivity decreased concomitantly with increasing time after the Fukushima Dai-ichi NPP accident. However, the radioactivity of ${ }^{134} \mathrm{Cs}$ and ${ }^{137} \mathrm{Cs}$ in the high flow condition after the typhoon was about one order higher than that in normal flow conditions, which indicates that high export of ${ }^{134} \mathrm{Cs}$ and ${ }^{137} \mathrm{Cs}$ occurred after the heavy rain event. The ${ }^{134} \mathrm{Cs} /{ }^{137} \mathrm{Cs}$ activity ratio for all samples is about 1.0 , corrected to 11 March 2011. These values are consistent with those of surface soil samples at $0-5 \mathrm{~cm}$ depth (Yamamoto et al., 2012; Matsunaga et al., 2013). Therefore, radiocesium derived from the Fukushima Dai-ichi NPP was transported from the deposited surface to rivers. The highest radioactivity is 2-3 orders higher than that collected in 1985-1988 from Japanese rivers (Hirose et al., 1980; Matsunaga et al., 1991).

\subsection{Existing forms of ${ }^{134} \mathrm{Cs}$ and ${ }^{137} \mathrm{Cs}$}

Figure 4 shows the total radioactivity of ${ }^{137} \mathrm{Cs}$ versus radioactivity of dissolved forms of ${ }^{137} \mathrm{Cs}$. In normal water flow conditions, dissolved forms of ${ }^{137} \mathrm{Cs}$ were $0.011-$ $0.064 \mathrm{~Bq} \mathrm{~L}^{-1}$, but in the high flow conditions, after the heavy rain event, dissolved ${ }^{137} \mathrm{Cs}$ was about $0.005 \mathrm{BqL}^{-1}$. These results indicate that heavy rains affect the export of radiocesium from the Fukushima Dai-ichi NPP accident that had 
Table 1. Water quality and radioactivity of ${ }^{134} \mathrm{Cs}$ and ${ }^{137} \mathrm{Cs}$ in water samples from the Natsui River and the Same River.

\begin{tabular}{lrrrrr}
\hline $\begin{array}{l}\text { Sampling } \\
\text { date }\end{array}$ & $\mathrm{pH}$ & $\begin{array}{r}\mathrm{WT} \\
\left({ }^{\circ} \mathrm{C}\right)\end{array}$ & $\begin{array}{r}{ }^{134} \mathrm{C} \\
\left(\times 10^{-3} \mathrm{BqL}^{-1}\right)\end{array}$ & $\begin{array}{r}{ }^{137} \mathrm{Cs} \\
\left(\times 10^{-3} \mathrm{BqL}^{-1}\right)\end{array}$ & ${ }^{134} \mathrm{Cs} /{ }^{137} \mathrm{Cs}^{*}$ \\
\hline Natsui River & & & & & \\
& & & & & \\
12 Jul 2011 & 7.6 & 29.5 & $49.0 \pm 1.3$ & $52.0 \pm 2.5$ & $1.06 \pm 0.06$ \\
27 Jul 2011 & 7.4 & 26.0 & $89.0 \pm 1.6$ & $98.0 \pm 2.5$ & $1.02 \pm 0.03$ \\
13 Sep 2011 & 7.3 & 25.5 & $25.2 \pm 1.2$ & $26.0 \pm 1.2$ & $1.14 \pm 0.07$ \\
22 Sep 2011 & 7.8 & 18.6 & $673.0 \pm 4.0$ & $853.0 \pm 4.0$ & $1.00 \pm 0.01$ \\
24 Nov 2011 & 7.6 & 10.9 & $61.5 \pm 1.8$ & $78.7 \pm 1.2$ & $0.97 \pm 0.03$ \\
6 Dec 2011 & 7.4 & 6.5 & $22.0 \pm 1.4$ & $27.7 \pm 1.6$ & $1.04 \pm 0.06$
\end{tabular}

Same River

\begin{tabular}{lrrrrr} 
12 Jul 2011 & 7.5 & 25.4 & $74.5 \pm 2.4$ & $81.0 \pm 2.2$ & $1.03 \pm 0.04$ \\
27 Jul 2011 & 7.5 & 23.4 & $47.5 \pm 5.9$ & $52.0 \pm 5.7$ & $0.99 \pm 0.16$ \\
13 Sep 2011 & 7.8 & 22.9 & $15.9 \pm 1.3$ & $18.9 \pm 1.2$ & $1.00 \pm 0.10$ \\
22 Sep 2011 & 7.9 & 18.6 & $360.0 \pm 3.0$ & $424.0 \pm 3.0$ & $1.01 \pm 0.01$ \\
24 Nov 2011 & 7.4 & 11.8 & $13.2 \pm 0.7$ & $15.3 \pm 0.6$ & $1.00 \pm 0.05$ \\
6 Dec 2011 & 7.5 & 8.5 & $8.9 \pm 1.0$ & $11.4 \pm 1.5$ & $1.10 \pm 0.13$ \\
\hline
\end{tabular}

$*{ }^{134} \mathrm{Cs} /{ }^{137} \mathrm{Cs}$ activity ratio was calculated after decay correction of ${ }^{134} \mathrm{Cs}$ and ${ }^{137} \mathrm{Cs}$ radioactivity on $11 \mathrm{March}$ 2011.

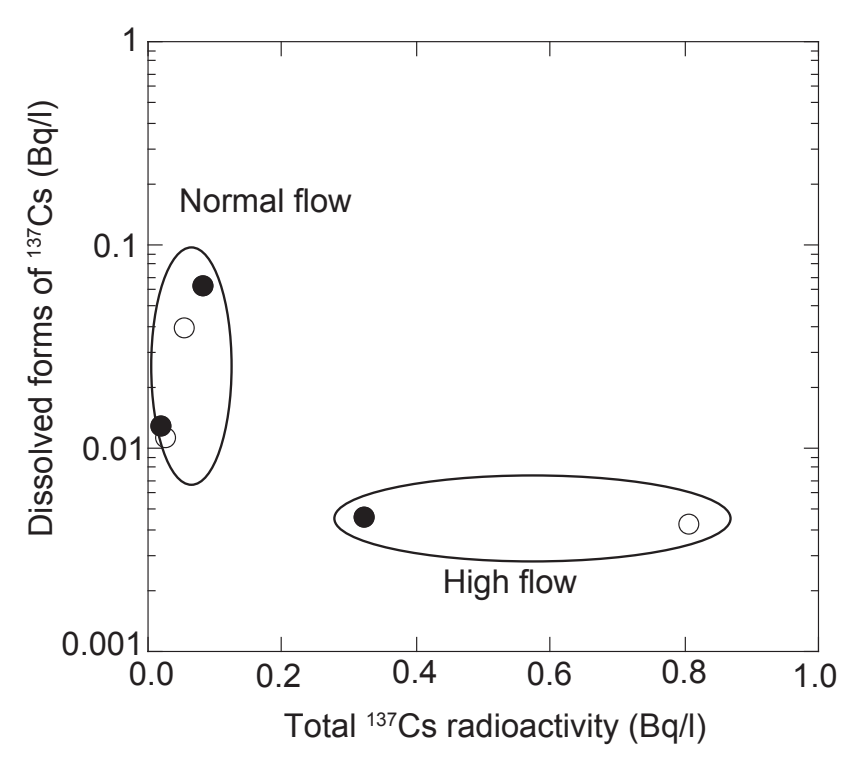

Fig. 4. Total and dissolved radioactivity of ${ }^{137} \mathrm{Cs}$ in river waters from the Natsui River (o) and the Same River (•).

been deposited on the ground surface. Similar results were reported for Ukraine river systems after the Chernobyl accident (Matsunaga et al., 1998).

Table 2 presents percentages of particulate phase ${ }^{137} \mathrm{Cs}$ at normal and high flow conditions in the Natsui River and the Same River after the Fukushima Dai-ichi NPP accident, together with results for the Kuji River before the Fukushima Dai-ichi NPP accident. At normal flow condi- tions, the percentage of particulate ${ }^{137} \mathrm{Cs}$ is $21-56 \%$ on average of $40 \pm 17 \%$. The other rivers in central to northern Japan were 11-47 \% (Hirose et al., 1990; Matsunaga et al., 1991). The Pripyat River had approximately 40-60\% of radiocesium in the particulate phase during the decade after the Chernobyl accident (Voitsekhovich et al., 1997). The effects of heavy rains reveal that a major part of ${ }^{137} \mathrm{Cs}$ is present as particulate phase in the Natsui River and the Same River. The particulate form of ${ }^{137} \mathrm{Cs}$ is predominant in river waters after the rain event in the Kuji River (Matsunaga et al., 1991).

As Table 3 shows, radioactivity of suspended solids is about $2000 \mathrm{~Bq} \mathrm{~kg}^{-1}$-dried suspended solids (ss). This value corresponds to that of river-bottom sediment (about $2000 \mathrm{~Bq} \mathrm{~kg}^{-1}$ : Ministry of the Environment, 2012) and soil in watershed (230-2400 Bq kg-1: MEXT, 2012b). ${ }^{134} \mathrm{Cs}$ and ${ }^{137} \mathrm{Cs}$ of fine particle fraction trapped on the filters in the river waters also show higher radioactivity content of $1548-2336 \mathrm{~Bq} \mathrm{~kg}^{-1}$-ss for the Natsui River and 7161$8649 \mathrm{~Bq} \mathrm{~kg}^{-1}$-ss for the Same River. Radiocesium associated with suspended solids suggests an important pathway from watersheds to rivers.

Figure 5 shows X-ray diffraction analysis for the suspended solids filtered with Advantec no. 5A filters (FR2), membrane filters with pore size of $0.45 \mu \mathrm{m}$ (FR3), and deposited suspended solids (FR1). Blank GF/F and membrane filters have their own characteristics such as a broad peak between 13 and $35^{\circ} 2 \theta$ and three peaks of $13-25^{\circ} 2 \theta$, respectively. All samples include clay minerals such as chlorite, vermiculite, smectite, mica, and kaolin. Clay mineral types in the fixation of radiocesium have been widely claimed (e.g., 
Table 2. Percentage of ${ }^{137} \mathrm{Cs}$ associated with suspended solids in Natsui River and Same River waters at low and high flow conditions

\begin{tabular}{llrrrl}
\hline River & Flow & condition & $\begin{array}{r}{ }^{137} \mathrm{C} \\
\left(\times 10^{-3} \mathrm{BqL}^{-1}\right)\end{array}$ & $\begin{array}{r}\text { Particulate } \\
137 \mathrm{Cs}(\%)\end{array}$ & $\begin{array}{r}\text { No. } \\
\text { sample }\end{array}$ \\
\hline Natsui $^{\mathrm{a}}$ & High & $49.0 \pm 1.3$ & $\sim 100$ & 1 & This study \\
& Normal & $89.5 \pm 1.6$ & $40 \pm 17$ & 2 & This study \\
Same $^{\mathrm{a}}$ & High & $25.2 \pm 1.2$ & 99 & 1 & This study \\
& Normal & $673.0 \pm 4.0$ & $26 \pm 5$ & 2 & This study \\
Kuji & High & $1.0^{\mathrm{c}}$ & 77 & 1 & Matsunaga et al. (1991) \\
& Normal & $0.12 \pm 0.06$ & $41 \pm 17$ & 12 & Matsunaga et al. (1991) \\
Kitakami & & 0.14 & 39 & 1 & Hirose et al. (1990) \\
Tone & & $0.77 \pm 0.59$ & $21 \pm 9$ & 6 & Hirose et al. (1990) \\
Ishikari & & $0.37 \pm 0.12$ & $47 \pm 31$ & 2 & Hirose et al. (1990) \\
Kuzuryu & & 1.17 & 11 & 1 & Hirose et al. (1990) \\
\hline
\end{tabular}

\footnotetext{
${ }^{a}$ Water discharge was $238-350 \mathrm{~m}^{3} \mathrm{~s}^{-1}$ in a high flow condition and $11.0-23.7 \mathrm{~m}^{3} \mathrm{~s}^{-1}$ in a normal flow condition.

${ }^{b}$ Water discharge was $75.4 \mathrm{~m}^{3} \mathrm{~s}^{-1}$ in a high flow condition and $8.1-59.4 \mathrm{~m}^{3} \mathrm{~s}^{-1}$ in a normal flow condition.

${ }^{\mathrm{c}}$ Proceeding precipitation was above $30 \mathrm{mmday}^{-1}$.
}

Table 3. Radioactivity of ${ }^{134} \mathrm{Cs}$ and ${ }^{137} \mathrm{Cs}$ of suspended solids in water samples from the Natsui River and the Same River collected on 22 September 2011 after Typhoon Roke.

\begin{tabular}{llrrr}
\hline Sample & $\begin{array}{l}\text { Suspended } \\
\text { solid }(\mathrm{g})\end{array}$ & $\begin{array}{r}{ }^{134} \mathrm{C} \\
\left(\mathrm{Bq} \mathrm{kg}^{-1}-\mathrm{ss}\right)\end{array}$ & $\begin{array}{r}{ }^{137} \mathrm{Cs} \\
\left(\mathrm{Bq} \mathrm{kg}^{-1}-\mathrm{ss}\right)\end{array}$ & ${ }^{134} \mathrm{Cs} /{ }^{137} \mathrm{Cs}^{*}$ \\
\hline Natsui River & & & & \\
FR1 & 6.88 & $1980 \pm 11$ & $2336 \pm 11$ & $1.00 \pm 0.01$ \\
FR2 & 0.096 & $1548 \pm 58$ & $1817 \pm 64$ & $1.03 \pm 0.04$ \\
FR3 & 0.362 & $1934 \pm 70$ & $2303 \pm 76$ & $0.97 \pm 0.04$ \\
Same River & & & & \\
FR1 & 3.42 & $1569 \pm 14$ & $1865 \pm 14$ & $1.01 \pm 0.01$ \\
FR2 & 0.062 & $7176 \pm 113$ & $8268 \pm 127$ & $1.03 \pm 0.02$ \\
FR3 & 0.182 & $7691 \pm 81$ & $8649 \pm 93$ & $1.03 \pm 0.01$ \\
\hline
\end{tabular}

ss is suspended solids in river water.

Decay correction of radioactivity for ${ }^{134} \mathrm{Cs}$ and ${ }^{137} \mathrm{Cs}$ was done each sampling date.

${ }^{*}{ }^{134} \mathrm{Cs} /{ }^{137} \mathrm{Cs}$ activity ratio was calculated after decay correction of ${ }^{134} \mathrm{Cs}$ and ${ }^{137} \mathrm{Cs}$ radioactivity on

11 March 2011 .

Facchinelli et al., 2001; Korobova et al., 2007). For example, an increase in ${ }^{137} \mathrm{Cs}$-specific activity was observed in floodplain soil with increased smectite content in clay fractions (Korobova et al., 2007). Selective sorption of ${ }^{137}$ Cs has been reported for illite and mica at laboratory experimental systems (Brouwer et al., 1983; Staunton and Roubaud, 1997). Therefore, clay minerals in suspended solids from the Natsui River and the Same River appear to have fixation and/or association capability for ${ }^{134} \mathrm{Cs}$ and ${ }^{137} \mathrm{Cs}$. However, X-ray diffraction data for size-fractionated samples can not estimate the percentage of each clay mineral because of the small amounts of samples and their crystallinity. Future studies are expected to provide detailed characterization of suspended solids in the Same River and Natsui River.

\subsection{Migration behavior of ${ }^{134} \mathrm{Cs}$ and ${ }^{137} \mathrm{Cs}$ in river systems}

Distribution coefficient $\left(K_{\mathrm{d}}\right)$ between suspended solids and river water is defined as

$K_{\mathrm{d}}=C_{\text {solid }} / C_{\text {dissolved }}$,

where $C_{\text {solid }}$ and $C_{\text {dissolved }}$ respectively denote the ${ }^{137} \mathrm{Cs}$ concentrations in the suspended solids $\left(\mathrm{Bqg}^{-1}\right)$ and dissolved phase $\left(\mathrm{Bq} \mathrm{mL}^{-1}\right)$. The fate and bioavailability depend strongly on the $K_{\mathrm{d}}$ and strength of the particle-contaminant association. Estimation of $K_{\mathrm{d}}$ values was conducted using data from measurements presented in Tables 1 and 3. The $K_{\mathrm{d}}$ is $0.43-0.55 \times 10^{6} \mathrm{~mL} \mathrm{~g}^{-1}$ for the Natsui River and $4.1-5.0$ $\times 10^{6} \mathrm{~mL} \mathrm{~g}^{-1}$ for the Same River. These values are $1-2$ orders higher than those of other Japanese rivers such as the Tone River and the Ishikari River (Hirose et al., 1990) and the Kuji River (Matsunaga et al., 1991) before the Fukushima Daiichi NPP accident. The $K_{\mathrm{d}}$ values of the Fukushima rivers are 
also two orders higher than that of Ukraine after the Chernobyl accident (Matsunaga et al., 1998), which is regarded as supplying suspended solids from the watershed and resuspension of river bottom sediments by rain events.

The cumulative ${ }^{134} \mathrm{Cs}$ and ${ }^{137} \mathrm{Cs}$ inventory from the surface down to depth in undisturbed soils in Fukushima Prefecture confirms that $>90 \%$ of the total ${ }^{134} \mathrm{Cs}$ and ${ }^{137} \mathrm{Cs}$ in the soil profile was found within the upper $5 \mathrm{~cm}$ layer at cropland and grassland sites (Koarashi et al., 2012). Surface erosion processes in watersheds have been studied by many researchers using ${ }^{137} \mathrm{Cs}$ derived from fallout as a tracer of suspended solids. Surface runoff generally does not occur in forested areas, but unmanaged Japanese cypress plantations often have little surface cover. For that reason, surface runoff is generated in such areas during large rainstorms (Miyata et al., 2007; Gomi et al., 2008). Fukuyama et al. (2010) reported for different stand species that surface coverage and forest management practices affect the runoff of the surfacederived suspended solids at the catchment scale. To elucidate the effects of input of suspended solids on $K_{\mathrm{d}}$ value, we compared the $K_{\mathrm{d}}$ values after heavy rain events caused by a typhoon in September 2011 and July 2012. The suspended solid concentration was $0.20-0.41 \mathrm{gl}^{-1}$ for the September samples and 0.26-0.34 $\mathrm{gl}^{-1}$ (Nagao unpublished data) for the July samples. The dissolved radiocesium activity was almost equal for both sampling dates: $0.0025-0.0046 \mathrm{~Bq} \mathrm{~L}^{-1}$. The $K_{\mathrm{d}}$ values of ${ }^{134} \mathrm{Cs}$ and ${ }^{137} \mathrm{Cs}$ for the July samples were $0.20-0.43 \times 10^{6} \mathrm{~mL} \mathrm{~g}^{-1}$ and still high, although the values were $1 / 2-1 / 10$ lower than that of 2011 September samples. These results suggest that the source of particulate forms of radiocesium is an important factor controlling $K_{\mathrm{d}}$ values related to secondary dispersion after the nuclear accident. Suspended solids are derived primarily from the erosion of riverbanks and hill slope soils by overland flow (Knighton, 1998; Ritter et al., 2002). The riverbank erosion and resuspension of river bottom sediments are important sources of particulate ${ }^{137} \mathrm{Cs}$ in river waters after rain events (Matsunaga et al., 1991). Direct input of suspended solids eroded from the ground surface might be reflected in the higher values found for the Natsui River and the Same River after heavy rains at the initial stage of the Fukushima Dai-ichi NPP accident.

The ${ }^{134} \mathrm{Cs}$ and ${ }^{137} \mathrm{Cs}$ radioactivity in the riverside surface soil at Samegawa-Ohashi, located downstream along the Same River, was 22-970 Bq kg ${ }^{-1}$ during September 2011November 2012 (Ministry of Environment in Japan, 2012). The radioactivity at Idosawa-Ohashi, an upper downstream location, was 70-900 $\mathrm{Bq} \mathrm{kg}^{-1}$ during September 2011-July 2012, but $1500-7100 \mathrm{~Bq} \mathrm{~kg}^{-1}$ on 2 September and 9 November 2012 at high water level conditions. These results suggest that ${ }^{134} \mathrm{Cs}$ and ${ }^{137} \mathrm{Cs}$ were deposited on the riverside surface soil as a result of rain events.

The radioactivity of ${ }^{134} \mathrm{Cs}$ and ${ }^{137} \mathrm{Cs}$ deposited in river bottom sediments was approx. $770 \mathrm{~Bq} \mathrm{~kg}^{-1}$-sediment for the Natsui River and approx. $2000 \mathrm{~Bq} \mathrm{~kg}^{-1}$ for the Same River during May-July 2011, but $10-250 \mathrm{~Bq} \mathrm{~kg}^{-1}$ during Septem- ber 2011-November 2012 (Ministry of the Environment, 2012). The radioactivity varied with sampling, although the samplings were conducted at fixed stations in each river. The river bottom sediments are sandy, so the apparent residence time of fine particles might be short in the Natsui River and the Same River because of flushing out that occurs concomitantly with rain events. Therefore, the contaminated area around the river basin and river bottom sediments plays an important role as a source of particulate phase ${ }^{134} \mathrm{Cs}$ and ${ }^{137} \mathrm{Cs}$ in river waters.

Figure 6 presents a schematic illustration showing the export of radiocesium from the watershed to a river. Erosion of the riverbank and ground surfaces, along with re-suspension of river bottom sediments, occurs during rain events, thereby increasing the amounts of suspended solids and the radioactivity of ${ }^{134} \mathrm{Cs}$ and ${ }^{137} \mathrm{Cs}$ associated with riverine suspended solids. Similar results have been reported for the Kuji River, running through Ibaraki and Fukushima prefectures (Matsunaga et al. 1998). Increased erosion and radioactivity of ${ }^{137}$ Cs derived from global fallout have also been observed at the Kuzuryuu River in 2009 after rain events (Nagao, unpublished data).

\subsection{Estimation of radiocesium flux from watersheds}

To ascertain the impacts of heavy rains on the transport of radiocesium and its dispersion to coastal ocean, flux of radiocesium from land areas through rivers to the ocean was estimated simply based on our measurements, as shown in Table 1, and from water discharge data (Fukushima Prefectural Government, 2011). In the Natsui River, the averaged radioactivity was $0.0493 \pm 0.0276 \mathrm{~Bq} \mathrm{~L}^{-1}$ for ${ }^{134} \mathrm{Cs}$ and $0.0566 \pm 0.0315 \mathrm{~Bq} \mathrm{~L}^{-1}$ for ${ }^{137} \mathrm{Cs}$, except for the sample taken after the heavy rain. Mean monthly water discharge was $17.6 \pm 30.8 \mathrm{~m}^{3} \mathrm{~s}^{-1}$ during March-December 2011. The fluxes $(F)$ of ${ }^{134} \mathrm{Cs}$ and ${ }^{137} \mathrm{Cs}$ are defined as

$F=C \times \mathrm{WD} \times T$,

where $C$ stands for the mean radioactivity of ${ }^{137} \mathrm{Cs}$ except for the heavy rain sample, WD signifies the mean monthly water discharge, and $T$ denotes the period of 11 March31 December 2011. The fluxes of radiocesium from land to ocean are estimated as $2.3 \pm 4.2 \mathrm{~Bq} / 305$ days for ${ }^{134} \mathrm{Cs}$ and $2.6 \pm 4.8 \times 10^{10} \mathrm{~Bq} / 305$ days for ${ }^{137} \mathrm{Cs}$. The radioactivity of ${ }^{137}$ Cs during 1 January-10 March might resemble that before the Fukushima Dai-ichi NPP accident and 2-3 order lower values. Therefore, the estimated value corresponds to the annual export flux.

Regarding the heavy rain event, the mean daily water discharge was $350 \pm 264 \mathrm{~m}^{3} \mathrm{~s}^{-1}$, as calculated from hourly water discharge on 22 September 2011. The radioactivity levels of ${ }^{134} \mathrm{Cs}$ and ${ }^{137} \mathrm{Cs}$ were, respectively, $0.673 \pm 0.004 \mathrm{~Bq} \mathrm{~L}^{-1}$ and $0.853 \pm 0.004 \mathrm{~Bq} \mathrm{~L}^{-1}$. Therefore the fluxes from river to ocean were $2.0 \pm 1.5 \times 10^{10} \mathrm{~Bq} \mathrm{day}^{-1}$ for ${ }^{134} \mathrm{Cs}$ and $2.6 \pm 1.9$ $\times 10^{10} \mathrm{~Bq} \mathrm{day}^{-1}$ for ${ }^{137} \mathrm{Cs}$ on 22 September 2011 . This value, 

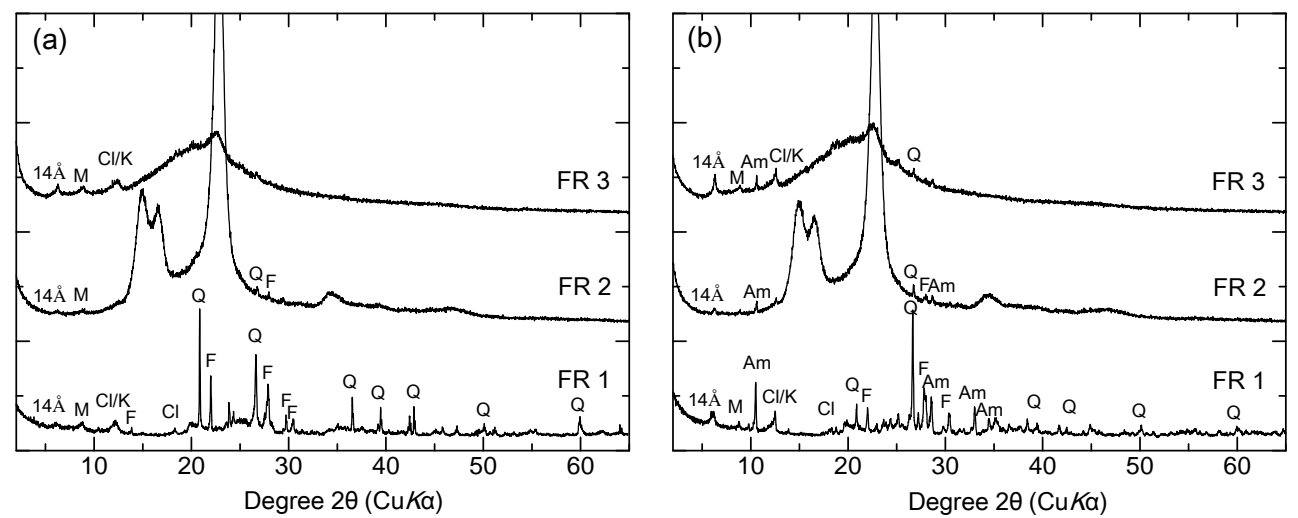

Fig. 5. X-ray diffraction patterns of suspended solids in the Natsui River (a) and Same River (b) after the heavy rain event (Typhoon Roke) in 2011. Legend for abbreviations of minerals: $14 \AA$ - chlorite, vermiculite, smectite; M - mica; Am - amphibole; F - feldspar; Q - quartz; $\mathrm{Cl} / \mathrm{K}$ - chlorite and/or kaolin.
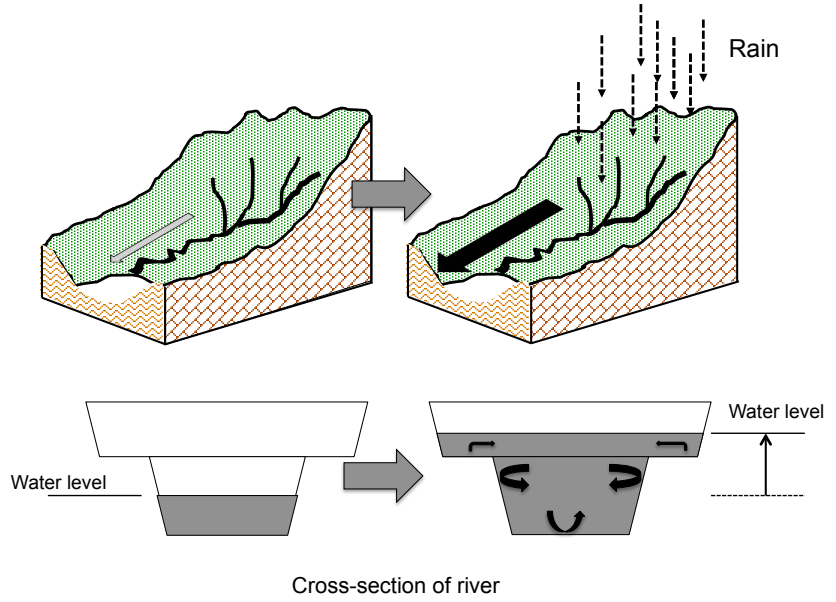

Fig. 6. Schematic illustrations of export of ${ }^{134} \mathrm{Cs}$ and ${ }^{137} \mathrm{Cs}$ from watersheds to rivers.

which corresponds to that for March-December 2011, represents a rough estimation because of a lack of consideration for the six rain events with precipitation greater than $50 \mathrm{~mm}$ monitored at the Onahama site (JMA, 2012). The monitoring sites in the Natsui River and Same River are located at ca. $4-11 \mathrm{~km}$ from the river mouths. From the present dataset, we can not ascertain the transport behavior of radiocesium at the river mouth. However, Fujita et al. (2001) observed that turbidity in river water at the mouth of Same River increased to $150 \mathrm{ppm}$ after the rain event with $47 \mathrm{~mm} \mathrm{day}^{-1}\left(14.4 \mathrm{~mm} \mathrm{hr}^{-1}\right)$ in September 2000, which suggests that some suspended solids were transported from the lower river to the river mouth. Consequently, we can infer the importance of rain events for radiocesium transport from watersheds to rivers during the year.

Table 4 shows flux data of ${ }^{137} \mathrm{Cs}$ for the Natsui River and the Same River together with those from other river systems. The flux at the Same River was estimated using a simple method similar to that used in this study. As Table 4 shows, the export flux in Fukushima rivers in 2011 is one order higher than that of the Tone River in 1985-1986 and the Kuji River in 1988-1989. The heavy rain event by Typhoon Roke on 22 September occupied $30-50 \%$ of the annual export flux. These results indicate that the heavy rain event is one factor determining the export of ${ }^{134} \mathrm{Cs}$ and ${ }^{137} \mathrm{Cs}$ in the Natsui River and the Same River.

\section{Summary}

During July-December, 2011, research was conducted for the Natsui River and the Same River, which run through a contaminated watershed in Fukushima Prefecture, to elucidate the transport of ${ }^{134} \mathrm{Cs}$ and ${ }^{137} \mathrm{Cs}$ from land to coastal ocean area after the Fukushima Dai-ichi NPP accident. The levels of ${ }^{134} \mathrm{Cs}$ and ${ }^{137} \mathrm{Cs}$ radioactivity were measured for river water samples in normal flow conditions and high flow conditions caused by a heavy rain event with daily precipitation of $137 \mathrm{~mm}$ (Typhoon Roke) in September 2011. The ${ }^{134} \mathrm{Cs}$ and ${ }^{137} \mathrm{Cs}$ radioactivity levels in a normal flow condition were $0.009-0.098 \mathrm{BqL}^{-1}$, but at a high flow condition, they were $0.36-0.85 \mathrm{~Bq} \mathrm{~L}^{-1}$. Particulate phase of ${ }^{134} \mathrm{Cs}$ and ${ }^{137} \mathrm{Cs}$ was $21-56 \%$ in a normal flow condition and ca. $100 \%$ in a high flow condition. Therefore, radiocesium associated with suspended solids is exported in large quantities from river to coastal ocean areas by heavy rains. Export of ${ }^{134} \mathrm{Cs}$ and ${ }^{137} \mathrm{Cs}$ after the heavy rain event is estimated as roughly 2.0-2.6 $\times 10^{10} \mathrm{~Bq} \mathrm{day}^{-1}$ for the Natsui River and 0.74-0.87 $\times 10^{10} \mathrm{~Bq} \mathrm{day}^{-1}$ for the Same River. These values account for $30-50 \%$ of the export of radiocesium for the 10 months of 11 March-31 December 2011 in both rivers. Therefore, results show that pulse input by heavy rain events is one important pathway of radiocesium from inland to coastal ocean areas in the southern part of Fukushima Prefecture, Japan. 
Table 4. Export fluxes of ${ }^{137} \mathrm{Cs}$ from land to ocean in the Natsui, Same, Kuji and Tone rivers.

\begin{tabular}{lrrrrrr}
\hline River & $\begin{array}{r}\text { Catchment } \\
\text { area } \\
\left(\mathrm{km}^{2}\right)\end{array}$ & $\begin{array}{r}\text { Export flux of } \\
\text { Annual }\end{array}$ & $\begin{array}{r}{ }^{137} \mathrm{C} \\
\text { Heavy rain } \\
\left(\times 10^{10} \mathrm{~Bq} \mathrm{yr}^{-1}\right)\end{array}$ & $\begin{array}{r}\text { Contribution } \\
\text { of heavy rain } \\
\left(\times 10^{10} \mathrm{~Bq} \mathrm{day}^{-1}\right)\end{array}$ & $\begin{array}{r}\text { Year } \\
(\%)\end{array}$ & $\begin{array}{r}\text { Major } \\
\text { origin } \\
\text { of }\end{array}$ \\
\hline Natsui & 749 & $5.2 \pm 1.3$ & $2.6 \pm 1.9$ & 50 & 2011 & NA \\
Same & 600 & $2.9 \pm 1.2$ & $0.87 \pm 0.92$ & 30 & 2011 & NA \\
Kuji* & 1490 & 0.26 & - & - & 1988 & GF \\
Tone** & 16840 & $0.50 \pm 0.38$ & - & - & 1985 & GF \\
\hline
\end{tabular}

NA indicates nuclear accident, and GF is global fallout.

* Flux estimates from ${ }^{137}$ Cs annual load (Matsunaga et al., 1991) and watershed area of the Kuji River.

** Flux estimates from the average radioactivity of ${ }^{137} \mathrm{Cs}$ (Hirose et al., 1990) and mean annual water discharge in 1985 (MLIT, 2012).

Acknowledgements. The authors wish to thank S. Nishimura of Kanazawa University for assisting in the filtration of river water samples. This study was partly funded by Grants-in-Aid for Scientific Research from the Ministry of Education, Culture, Sports, Science and Technology, Japan (No. 24310009 and 24110008-01).

Edited by: Minhan Dai

\section{References}

Brouwer, E., Baeyens, B., Maes, A., and Cremers, A. J.: Cesium and rubidium ion equilibria in illite clay, Phys. Chem., 87, 12131219, 1983.

Chino, M., Nakayama, H., Nagai, H., Terada, H., Katata, G., and Yamazawa, H.: Preliminary estimation of release amounts of ${ }^{131} \mathrm{I}$ and ${ }^{137}$ Cs accidentally discharged from the Fukushima Daiichi Nuclear Power Plant into the atmosphere, J. Nucl. Sci. Technol., 48, 1129-1134, 2011.

Facchinelli, A., Gallinia, L., Barberisb, E., Magnonic, M., and Hursthouse, A. S.: The influence of clay mineralogy on the mobility of radiocaesium in upland soils of NW Italy, J. Environ. Radioact., 56, 299-307, 2001.

Fujita, R., Kumagaya, T., Sato, S., Isobe, M., and Kajimura, T.: Insitu measurements of wave-current and suspended solids transport in Nakoso coastal area. Proceedings of Coastal Engineering, Japan Society of Civil Engineers, 48, 651-655, 2001 (in Japanese).

Fukushima Prefectural Government: Data on water discharge of the Natsui River and Same River in 2011, 2012 (in Japanese).

Fukuyama, T., Onda, Y., Gomi, T., Yamamoto, K., Kondo, N., Miyata, S., Kosugi, K., Mizugaki, S., and Tsubonuma, N.: Quantifying the impact of forest management practice on the runoff of the surface-derived suspended sediment using fallout radionuclides, Hydrol. Process., 24, 596-607, 2010.

Gomi, T., Asano, Y., Uchida, T., Onda, Y., Sidle, R. C., Miyata, S., Kosugi, K., Mizugaki, M., Fukuyama, T., and Fukushima, T.: Evaluation of storm runoff pathways in steep nested catchments draining a Japanese cypress forest in central Japan: a geochemical approach, Hydrol. Process., 24, 550-566, 2008.

Hamajima, Y. and Komura, K.: Low level counting in Ogoya Underground Laboratory, in: Proc. Int. Workshop on Low-level Measurement of Radionuclides and its Application to Earth and En- vironmental Sciences, Nomi, Japan, 5-6 September 2010, 1-8, 2010.

Hirose, K., Aoyama, M., and Sugimura, Y.: Plutonium and cesium isotopes in river waters in Japan, J. Radioanal. Nucl. Ch., 141, 191-202, 1990.

International Atomic Energy Agency (IAEA): Environmental Consequences of the Chernobyl Accident and Their Remediation: Twenty Years of Experience, Vienna, Austria, 2006a.

International Atomic Energy Agency (IAEA): Radiological Conditions in the Dnieper River Basin: Assessment by an International Expert Team and Recommendations for as Action Plan, Vienna, Austria, 2006b.

Japan Meteorological Agency (JMA): Preliminary Report of Storm and Heavy Rain by Typhoon 15, 2011, available at: http://www.data.jma.go.jp/obd/stats/data/bosai/report/ new/jyun_sokuji20110915-0922.pdf, 2011.

Japan Meteorological Agency (JMA): Information on statistics data, available at: http://www.data.jma.go.jp/obd/stats/etrn/ view/nml_sfc_10d.php?prec_no=36\&block_no=47598\&year= $\&$ month $=\&$ day $=\&$ view $=, 2012$.

Japanese Government: Report of Japanese Government to the IAEA Ministerial Conference on Nuclear Safety - The Accident at TEPCO's Fukushima Nuclear Power Stations, 2011, available at: http://www.kantei.go.jp/foreign/kan/topics/201106/iaea_ houkokusho_e.html, 2011 (in Japanese).

Knighton, D.: Fluvial Forms and Processes: A New Prospective, Arnold, London, 1998.

Koarashi, J., Atarashi-Andoh, M., Matsunaga, T., Sato, T., Nagao, S., and Nagai, H.: Factors affecting vertical distribution of Fukushima accident-derived radiocesium in soil under different land-use conditions, Sci. Total Environ., 431, 392-401, 2012.

Korobova, E. M. and Chizhikova, N. P.: Distribution and mobility of radiocesium in relation to the clay fraction mineralogy and soil properties in the Iput River floodplain, Eurasian Soil Sci., 40, 1062-1075, 2007.

Matsunaga, T., Amano, H., and Yanase, N.: Discharge of dissolved and particulate ${ }^{137} \mathrm{Cs}$ in the Kuji River Japan, Appl. Geochem., 6, 159-167, 1991 .

Matsunaga, T., Ueno, T., Amano, H., Tkachenko, Y., Kovalyov, A., Watanabe, M., and Onuma, Y.: Characteristics of Chernobylderived radionuclides in particulate form in surface waters in the exclusion zone around the Chernobyl Nuclear Power Plant, J. Contam. Hydrol., 35, 101-113, 1998. 
Matsunaga, T., Koarashi, J., Atarashi-Andoh, M.-A., Nagao, S., Sato, T., and Nagai, H.: Comparison of the vertical distributions of Fukushima nuclear accident radiocesium in soil before and after the first rainy season, with physicochemical and mineralogical interpretations, Sci. Total Environ., 447, 301-314, 2013.

Ministry of Education, Culture Sports, Science and Technology in Japan (MEXT), available at: http://radioactivity.mext.go.jp/en/ contents/4000/3179/24/1270_1216.pdf, 2011.

Ministry of Education, Culture Sports, Science and Technology in Japan (MEXT): Report of research with distribution map of radiation dose, available at: http://radioactivity.mext.go.jp/old/ja/distribution_map_around_ FukushimaNPP/5600_201203131000_report2-1.pdf, 2012a.

Ministry of Education, Culture Sports, Science and Technology in Japan (MEXT): Monitoring information of environmental radioactivity level, available at: http://radioactivity.mext.go.jp/en, 2012b.

Ministry of Land, Infrastructure, Transport and Tourism in Japan (MLIT): Report on water resources in Japan, available at: http://www.mlit.go.jp/river/pamphlet_jirei/bousai/saigai/ kiroku/suigai/suigai_3-1-1.html, 2012.

Ministry of the Environment in Japan, available at: http://www.env. go.jp/jishin/monitoring/results_r-pw.html\#fukushima, 2012 (in Japanese).

Miyata, S., Kosugi, K., Gomi, T., Onda, Y., and Mizuyama, T.: Occurrence of surface runoff affected by soil water repellency at a hillslope covered with Japanese cypress Chamaecyparis obtusa, Hydrol. Process., 21, 2365-2376, 2007.

Morino, Y., Ohara, T., and Nishizawa, M.: Atmospheric behavior, deposition, and budget of radioactive materials from the Fukushima Daiichi nuclear power plant in March 2011, Geophys. Res. Lett., 38, L00G11, doi:10.1029/2011GL048689, 2011.

Nagano, T., Yanase, N., Tsutsuki, K., and Nagao, S.: Particulate and dissolved loads in the Kuji River related to discharge rate, Environ. Int., 28, 649-658, 2003.

Ritter, D. F., Kochel, R. C., and Miller, J. R.: Process Geomorphology, 4 Edn., McGraw-Hill, New York, 2002.
Sakaguchi, A., Kadokura, A., Steier, P., Tanaka, K., Takahashi, Y., Chiga, H., Matsushima, A., Nakashima, S., and Onda, Y.: Isotopic determination of $\mathrm{U}, \mathrm{Pu}$ and $\mathrm{Cs}$ in environmental waters following the Fukushima Daiichi Nuclear Power Plant accident, Geochem. J., 46, 355-360, 2012.

Saxén, R. and Ilus, E.: Discharge of ${ }^{137} \mathrm{Cs}$ and ${ }^{90} \mathrm{Sr}$ by Finnish rivers to the Baltic Sea in 1986-1996, J. Environ. Radioactiv. 54, 275-291, 2001.

Spezzano, P., Bortoluzzi, S., Giacomelli, R., and Massironi, L. Seasonal variations of ${ }^{137} \mathrm{Cs}$ activities in the Dora Baltea River (northwest Italy) after the Chernobyl accident, J. Environ. Radioactiv., 22, 77-88, 1994.

Staunton, S. and Roubaud, M.: Adsorption of ${ }^{137}$ Cs on montmorillonite and illite: effect of charge compensating cation, ionic strength, concentration of $\mathrm{Cs}, \mathrm{K}$ and fulvic acid, Clay Clay Miner., 45, 251-260, 1997.

Suetsugu, T.: River Science, Natsume, Tokyo, 2005 (in Japanese).

Tanaka, K., Inoue, M., Misono, J., and Komura, K.: Vertical profiles of ${ }^{226} \mathrm{Ra},{ }^{228} \mathrm{Ra}$ and ${ }^{137} \mathrm{Cs}$ activities in seawater around the Yamamoto Ridge and coastal areas of the Sea of Japan, Chikyu Kagaku, Geochemistry, 40, 167-176, 2006 (in Japanese).

Ukrainian Hydro-Meteorological Institute: Database of radiation measurements of aquatic samples, 2004.

Voitsekhovich, O. V., Nasvit, O., Los, I., and Berkovski, V.: Present thoughts on aquatic countermeasures applied to regions of the Dnieper River catchment contaminated by the 1986 Chernobyl accident, in: Freshwater and Estuarine Radioecology, edited by: Desmet, G., Blust, R., Comans, R. N. J., Fernandez, J. A., Hilton, J., and de Bettencourt, A., Elsevier, Amsterdam, 75-86, 1997.

Yamamoto, M., Takada, T., Nagao, S., Koike, T., Shimada, K., Hoshi, M., Zhumgdilov, K., Shima, T., Fukuoka, M., Imanaka, T., Endo, S., Sakaguchi, A., and Kimura, S.: An early survey of the radioactive contamination of soil due to the Fukushima Daiichi Nuclear Power Plant accident with emphasis on plutonium analysis, Geochem. J., 46, 341-353, 2012.

Yoshida, N. and Takahashi, Y.: Land-surface contamination by radionuclides from the Fukushima Daiichi Nuclear Power Plant accident, Elements, 8, 201-206, 2012. 